\title{
Analysis of saliva for antibodies to the LPS of Escherichia coli O157 in patients with serum antibodies to E. coli O157 LPS
}

\section{Correspondence \\ Henrik Chart \\ hchart@phls.org.uk}

Received 18 November 2002

Accepted 31 March 2003

\author{
Henrik Chart, Neil T. Perry, Geraldine A. Willshaw and Thomas Cheasty \\ Laboratory of Enteric Pathogens, Division of Gastrointestinal Infections, Central Public Health \\ Laboratory, 61 Colindale Avenue, London NW9 5HT, UK
}

\begin{abstract}
The salivary antibody response to the Escherichia coli O157 LPS antigen was assessed in 44 patients with serum antibodies binding to the LPS of E. coliO157. Saliva from 477 controls was also examined to assess the specificity of the immunoassay used. Twenty of the 44 patients had salivary antibodies to E. coliO157 LPS, giving the salivary antibody test a sensitivity of 0.45 and a predictive positive value for seropositivity of 1.00 . The presence of these antibodies appeared not to relate to the time interval between serum sampling and saliva sampling. None of the 477 volunteers had salivary antibodies binding to the LPS of E. coli $\mathrm{O} 157$ alone; however, 15 had antibodies which bound non-specifically to both O157 LPS and BSA.
\end{abstract}

\section{INTRODUCTION}

Verocytotoxin-producing Escherichia coli (VTEC) of serotype O157:H7 and O157:H- continue to be a cause of bloody diarrhoea, haemorrhagic colitis and haemolytic uraemic syndrome (HUS) in the UK (Simmons, 1997). Patients infected with E. coli $\mathrm{O} 157$ produce serum antibodies to the O157 LPS antigens (Chart \& Jenkins, 1999), and these antibodies form the basis for routine serological tests providing evidence of infection in the absence of faecal $E$. coli O157 (Thomas et al., 1996). The kinetics of serum antibody production during pathogenesis of infection with E. coli $\mathrm{O} 157$ has not been investigated thoroughly due to a paucity of sequential sera from patients. However, a recent study involving a single patient showed that the primary response involved high levels of IgM-class antibodies to O157 LPS, peaking at 10 days post onset of disease. Reduction in levels of IgM-class antibodies coincided with the emergence of IgG-class antibodies to O157 LPS (Chart et al., 2002). In general, sera used for O157 serodiagnosis originate from samples of blood taken for blood biochemistry, and the time of blood sampling may not coincide with maximal levels of antibodies to E. coli O157 LPS. Additional blood samples tend not to be taken, and if an initial serum did not contain antibodies to E. coli O157 LPS, the cause of disease may go undetected.

Patients infected with E. coli $\mathrm{O} 157$ may also produce salivary antibodies to the O157 LPS antigen (Chart \& Jenkins, 1998), and the ease of taking samples of saliva would make this very

Abbreviations: HUS, haemolytic uraemic syndrome; VTEC, verocytotoxinproducing Escherichia coli. suitable for serodiagnosis, particularly for young children where taking samples of blood may be problematical. Analysis of sequential saliva samples would also increase the likelihood of testing patients when levels of antibodies were optimal. In the present study, 44 patients with serum antibodies to E. coli O157 LPS were examined for salivary antibodies with an O157-LPS-based ELISA combined with an immunoblotting procedure. Saliva from 477 controls was used to determine the likelihood of the immunoassay giving false-positive reactions.

\section{METHODS}

Patients. Forty-four patients were involved in this study (Tables 1 and 2) and all were shown to have serum antibodies to the LPS of E. coli O157 by routine serological analysis (Chart \& Jenkins, 1999). Twenty of the patients were female (mean age $27 \cdot 8$ years, $\sigma=23 \cdot 4$ years, $n=13$ ) and 13 male (mean age 18.3 years, $\sigma=15 \cdot 5$ years, $n=9$ ).

Symptoms included HUS (9), haemorrhagic colitis (1), diarrhoea (3) and bloody diarrhoea (1). Patients in whom serum antibodies to E. coli O157 were detected were requested to provide saliva samples; the time interval between the serum date and saliva date was calculated where a date of saliva sampling was provided (Tables 1 and 2). On receipt, sera were stored at $-30{ }^{\circ} \mathrm{C}$ until tested.

Saliva sampling. Samples of saliva were obtained using Oracol saliva test kits (Malvern Medical Developments). These comprised a sponge attached to a stick, enclosed within a plastic transport tube. The sponge-stick arrangement was used like a toothbrush, with the aim of absorbing saliva from both the mouth and the gingival crevices around the teeth. On arrival in the laboratory, the swabs were maintained at $4{ }^{\circ} \mathrm{C}$ until required for testing. Sponges were then detached, placed in a $5 \mathrm{ml}$ syringe and the saliva was pressed from the sponge. 
Table 1. Patients with serum and salivary antibodies to $E$. coli O157 LPS

\begin{tabular}{|lcl|}
\hline No. & Time (days)* & $\begin{array}{c}\text { Properties of VTEC O157 } \\
\text { where isolated } \dagger\end{array}$ \\
\hline 61 & 38 & \\
03 & 28 & PT 2 VT2 \\
53 & 27 & PT 21/28 VT2 \\
05 & 27 & PT 21/28 VT2 \\
42 & 26 & PT 21/28 VT2 \\
33 & 23 & \\
60 & 15 & PT 21/28 VT2 \\
59 & 15 & PT 21/28 VT2 \\
58 & 15 & PT 21/28 VT2 \\
57 & 15 & PT 21/28 VT2 \\
54 & 15 & PT 21/28 VT2 \\
50 & 15 & PT 21/28 VT2 \\
07 & 13 & \\
34 & 5 & PT 38 VT2 \\
24 & $?$ & PT 2 VT2 \\
17 & $?$ & PT 14 VT2 \\
08 & $?$ & \\
01 & $?$ & \\
06 & $?$ & PT 2 VT2 \\
26 & $?$ & \\
\hline
\end{tabular}

^Time in days between serum sample and saliva sample; ?, time between serum sample and saliva sample were not known.

$\dagger \mathrm{PT}$, phage type; VT, verocytotoxin type.

Volunteers. Samples of control saliva were obtained from 52 members of PHLS staff and their families; 23 were female (mean age $29 \cdot 2$ years, $\sigma=17 \cdot 4$ years, $n=23$ ) and 19 male (mean age $30 \cdot 3$ years, $\sigma=15 \cdot 75$ years, $n=19$ ). Samples of control saliva were also obtained from 425 children, under the age of 11 years, attending a Live Science exhibition at the Science Museum in London. The children comprised 173 girls (mean age $7 \cdot 8$ years, $\sigma=2 \cdot 1$ years) and 252 boys (mean age 7.7 years, $\sigma=2 \cdot 0$ years). Samples of saliva were screened by ELISA and those giving values $>0.5 A_{405}$ or equivocal results were tested by immunoblotting.

Isolation and characterization of VTEC 0157. Twenty-three of the 44 patients in the study had presumptive VTEC O157 isolated from their stools by clinical laboratories. These isolates were confirmed biochemically, serotyped, phage-typed and tested for the presence of verocytotoxin-encoding genes by the method summarized by Willshaw et al. (2001).

LPS. For SDS-PAGE and immunoblotting, LPS was prepared by digesting whole bacteria with proteinase K (Chart et al., 1989a). Bacteria were placed in pre-weighed Eppendorf tubes and the cells suspended in SDS-PAGE sample buffer (Laemmli, 1970) to give a concentration of $1 \mathrm{mg}$ per $30 \mu \mathrm{l}$ prior to incubation at $100{ }^{\circ} \mathrm{C}$ for $10 \mathrm{~min}$. After cooling, samples were mixed with an equal volume of SDS-PAGE buffer containing $100 \mu \mathrm{g}$ proteinase $\mathrm{K}$ (Sigma) per $30 \mu \mathrm{l}$ prior to incubation at $60{ }^{\circ} \mathrm{C}$ for $1 \mathrm{~h}$

For the ELISA, LPS was prepared from outer membranes (Chart, 1994) based on the hot-phenol method of Westphal \& Jann (1965). Outer membranes were suspended in $5 \mathrm{ml}$ deionized water and mixed with
Table 2. Patients with serum but not salivary antibodies to $E$. coli O157 LPS

\begin{tabular}{|c|c|c|}
\hline No. & Time (days)* & $\begin{array}{c}\text { Properties of VTEC } 0157 \\
\text { where isolated } \dagger\end{array}$ \\
\hline 22 & 44 & \\
\hline 82 & 39 & PT 49 VT2 \\
\hline 63 & 32 & \\
\hline 80 & 30 & \\
\hline 4 & 23 & PT 21/28 VT2 \\
\hline 2 & 16 & \\
\hline 52 & 15 & PT $21 / 28$ VT2 \\
\hline 55 & 15 & PT $21 / 28$ VT2 \\
\hline 51 & 15 & PT 21/28 VT2 \\
\hline 75 & 14 & \\
\hline 10 & 14 & \\
\hline 48 & 12 & PT $21 / 28$ VT2 \\
\hline 36 & 7 & PT 8, VT1 1 and 2 \\
\hline 77 & $?$ & PT 2 VT2 \\
\hline 114 & $?$ & PT $21 / 28$ VT2 \\
\hline 27 & $?$ & \\
\hline 25 & $?$ & \\
\hline 81 & $?$ & \\
\hline 100 & $?$ & \\
\hline 102 & $?$ & \\
\hline 73 & $?$ & \\
\hline 123 & $?$ & \\
\hline 101 & $?$ & \\
\hline 79 & $?$ & \\
\hline
\end{tabular}

*Time in days between serum sample and saliva sample; ?, time between serum sample and saliva sample were not known.

$\dagger \mathrm{PT}$, phage type; VT, verocytotoxin type.

$5 \mathrm{ml} 80 \%(\mathrm{w} / \mathrm{v})$ aqueous phenol solution (Merck). Following incubation at $68^{\circ} \mathrm{C}$ for $15 \mathrm{~min}$, the preparation was centrifuged $(3000 \mathrm{~g}$, $30 \mathrm{~min}, \mathrm{RT}$ ) and the aqueous phase was harvested and transferred to a clean glass container. The remaining phenol phase was mixed with $5 \mathrm{ml}$ deionized water, incubated at $68^{\circ} \mathrm{C}$ for $15 \mathrm{~min}$ and centrifuged (as above). The aqueous phase was removed and mixed with the initial aqueous phase fraction prior to dialysis against $3 \times 51$ deionized water at $4{ }^{\circ} \mathrm{C}$. The aqueous fraction was lyophilized and the LPS was weighed. The LPS was analysed by SDS-PAGE alongside LPS prepared from whole bacteria (see above). Profiles were stained with a silver stain for carbohydrate (Tsai \& Frasch, 1982) and showed that the purified LPS was representative of whole-cell LPS. They were also stained with a silver stain for protein (Wray et al., 1981) and shown not to contain contaminating cellular proteins.

SDS-PAGE and immunoblotting. SDS-PAGE was performed using an Atto mini-gel apparatus (Genetic Research Instruments). Preparations containing $83 \mu \mathrm{g}$ digested cell mass were used per lane, loaded onto gels ( $4.5 \%$ stacking gel and $12.5 \%$ separation gel) and electrophoresis was performed (50 mA) for $30 \mathrm{~min}$. Gels were either stained with silver to show LPS profiles (Tsai \& Frasch, 1982) or with Coomassie blue for proteins (Chart et al., 1989a), or profiles were transferred onto nitrocellulose paper (NCP) by immunoblotting (Chart et al., 1989a) $(0 \cdot 50 \mathrm{~A}, 1 \mathrm{~h})$. Profiles immobilized on sheets of NCP were blocked with 
$3 \%$ skimmed milk in PBS (milk-PBS; 30 min) and reacted with $30 \mu \mathrm{l}$ serum in $5 \mathrm{ml} \mathrm{milk-PBS}$ for $60 \mathrm{~min}$. After washing in PBS-Tween $(3 \times 10 \mathrm{~min})$, profiles were reacted with $5 \mu \mathrm{l}$ per lane of goat antihuman polyvalent Ig conjugated with alkaline phosphatase (Sigma) in skimmed milk-PBS (60 min). After washing, as above, profiles were placed in substrate buffer $(0.1 \mathrm{M}$ Tris, $0.09 \mathrm{M} \mathrm{NaCl}, 0.15 \mathrm{M}$ $\mathrm{MgCl}_{2} \cdot 6 \mathrm{H}_{2} \mathrm{O}$ ) for $10 \mathrm{~min}$. For colour development, NCP strips were placed in substrate buffer $(10 \mathrm{ml})$ containing $45 \mu \mathrm{l}$ nitro blue tetrazolium (Sigma; $75 \mathrm{mg} \mathrm{ml}^{-1}$ in $70 \%$ aqueous dimethyl formamide) and $35 \mu \mathrm{l}$ 5-bromo-4-chloro-3-indolylphosphate. $\mathrm{Na}_{2}$ (Sigma; $50 \mathrm{mg} \mathrm{ml}^{-1}$ in deionized water).

ELISA. The ELISA was performed (Chart et al., 1989a) using O157 LPS. Each sample of saliva was reacted with duplicate wells 'coated' with $1 \mu \mathrm{g}$ LPS in $100 \mu \mathrm{l}$ coating buffer $\left(1.59 \mathrm{~g} \mathrm{Na}_{2} \mathrm{CO}_{3}\right.$ and $2.93 \mathrm{~g} \mathrm{NaHCO}_{3} \mathrm{l}^{-1}$, $\mathrm{pH}$ 9.6) and 'blocked' with PBS containing BSA (10 $\mathrm{g}^{-1}$; Sigma). Samples were also reacted with a duplicate set of wells which had been blocked only. Samples of saliva ( $50 \mu \mathrm{l}$ per well) were added and antibody binding was detected with the same anti-human antibody conjugate as described for immunoblotting (above), diluted 1 in 1000 in PBS (50 $\mu \mathrm{l}$ per well). Antibodies conjugated with alkaline phosphatase were detected by adding $200 \mu \mathrm{l}$ diethanolamine buffer ( $1 \mathrm{M}$ diethanolamine, $2 \mathrm{mM} \mathrm{MgCl}_{2}, \mathrm{pH} 9 \cdot 6$ ) containing $1 \mathrm{mg}$ p-nitrophenol phosphate $\mathrm{ml}^{-1}$ (Sigma). The resultant colour was quantified by measuring the $A_{405}$. Samples with ELISA values of $>0.5 A_{405}$ or equivocal results were examined by immunoblotting (Chart et al., 1989b).

\section{RESULTS AND DISCUSSION}

Of the 44 patients with serum antibodies to O157 VTEC LPS, $20(45 \cdot 5 \%)$ also had salivary antibodies binding to O157 LPS as shown by immunoblotting (Table 1 ). This proportion was lower than observed in an earlier study (Chart \& Jenkins, 1998 ) where $62 \%$ of patients were identified with O157-LPSspecific salivary antibodies. The remaining 24 patients did not have detectable levels of salivary antibodies to O157 LPS, and the reasons for this remain unknown. The sensitivity of the salivary antibody test was calculated to be $45 \%$, with a predictive positive value of $100 \%$. This was considerably lower than the values obtained by Ludwig et al. (2002), who observed sensitivities of $100 \%$ and $92 \%$, respectively, for IgM- and IgG-class antibodies. The study by Ludwig et al. (2002) had the advantage of analysing sequential saliva samples from patients suspected of having been infected with E. coli O157. Regrettably, this was not possible in the present study where only single samples of saliva were obtained.

Of the 20 patients with salivary antibodies to O157 LPS, strains of VTEC O157 were isolated from 14 (70\%). These carried the genes encoding VT2 and nine belonged to PT 21/ 28 (Table 1). VTEC O157 was isolated from nine (37.5\%) of the remaining 24 patients with eight of nine strains carrying genes encoding VT2 and six belonging to PT 21/28 (Table 2). It was interesting to note that O157 VTEC was isolated from almost twice as many patients with salivary antibodies to O157 LPS as compared to those who did not have these antibodies, but the reasons for this are not known.

For the 20 patients with salivary antibodies to O157 VTEC LPS, the time intervals between submitting antibodypositive serum samples and the detection of anti-O157 antibodies in saliva samples ranged from 5 to 38 days (Table 1). For patients without salivary antibodies to O157 VTEC LPS, the time intervals between submitting antibodypositive serum samples and the receipt of saliva samples ranged from 7 to 44 days (Table 2). The time intervals between submitting serum samples and saliva samples, for patients with and without salivary antibodies to O157 LPS, were compared and found not to be significantly different $(\rho=0 \cdot 05)$. From this it was concluded that a proportion of serum-antibody-positive patients may simply not produce salivary antibodies to O157 LPS during infection with VTEC O157. Unfortunately, the study was hampered by the absence of clinical information relating to the time interval between onset of infection and the time of blood and saliva sampling.

The study also examined samples of saliva from two control groups. Based on an ELISA cut-off value of $0 \cdot 5 A_{405}$, none of the 52 PHLS volunteers had salivary antibodies binding to the LPS of E. coli O157 alone; however, eight (mean age 27.6, $\sigma=12 \cdot 5, n=5$ ) had salivary antibodies which bound nonspecifically to both O157 LPS and the ELISA plate blocking protein, BSA. Saliva samples from these eight were shown not to contain antibodies binding to O157 LPS by blotting.

Similarly, by ELISA none of the 425 children under the age of 11 years had salivary antibodies to O157 LPS, demonstrating that the immunoassays in this study were unlikely to produce false-positive results. Seven (mean age $=7 \cdot 4$ years, $\sigma=1 \cdot 6$ years, $n=7$ ) had salivary antibodies which also bound nonspecifically to both O157 LPS and BSA. The reasons for this are not known, but this result illustrated the importance of incorporating the appropriate controls in immunoassays of the type used in the present study. From the results obtained here and by others (Ludwig et al., 2002), and considering the detection of salivary antibodies to E. coli O157 LPS does not involve an invasive procedure, we suggest that clinicians investigating suspected cases of infection caused by E. coli O157 should consider having sequential samples of saliva analysed for antibodies to E. coli O157 LPS.

\section{ACKNOWLEDGEMENTS}

The authors would like to acknowledge all those who provided samples of serum and saliva from patients suspected of being infected with E. coli O157, and the healthy volunteers who provided control samples of saliva. The authors would also like to express their gratitude to the Food Standards Agency for funding this study, and the Science Museum, London, for holding their 'Live Science' exhibit which enabled the collection of control saliva samples.

\section{REFERENCES}

Chart, H. (1994). Bacterial fractionation and membrane protein characterization. In Methods in Practical Laboratory Bacteriology, pp. 1-20. Edited by H. Chart. Boca Raton, Ann Arbor, London, Tokyo: CRC Press.

Chart, H. \& Jenkins, C. (1998). Salivary antibodies to lipopolysaccharide antigens of Escherichia coli O157. Lancet 352, 371.

Chart, H. \& Jenkins, C. (1999). The serodiagnosis of infections caused by Verocytotoxin-producing Escherichia coli. J Appl Microbiol 86, 731-740. 
Chart, H., Scotland, S. M. \& Rowe, B. (1989a). Serum antibodies to Escherichia coli serotype O157:H7 in patients with hemolytic uremic syndrome. J Clin Microbiol 27, 285-290.

Chart, H., Scotland, S. M., Smith, H. R. \& Rowe, B. (1989b). Antibodies to Escherichia coli $\mathrm{O} 157$ in patients with haemorrhagic colitis and haemolytic uraemic syndrome. J Clin Pathol 42, 973-976.

Chart, H., Perry, N. T., Cheasty, T. \& Wright, P. A. (2002). The kinetics of antibody production to antigens of Escherichia coli $\mathrm{O} 157$ in a pregnant woman with haemolytic uraemic syndrome. J Med Microbiol 51, $522-525$.

Laemmli, U. K. (1970). Cleavage of structural proteins during the assembly of the head of bacteriophage T4. Nature 227, 680-685.

Ludwig, K., Grabhorn, E., Bitzan, M., Bobrowski, C., Kemper, M. J., Sobottka, I., Laufs, R., Karch, H. \& Muller-Wiefel, D. E. (2002). Saliva $\operatorname{IgM}$ and IgA are a sensitive indicator of the humoral immune response to Escherichia coli O157 lipopolysaccharide in children with enteropathic hemolytic uremic syndrome. Pediatr Res 52, 307-313.
Simmons, N. A. (1997). Global views on Escherichia coli O157 : H7 and other Verocytotoxic E. coli spp.: UK views. J Food Prot 60, 1463-1465.

Thomas, A., Cheasty, T., Frost, J. A., Chart, H., Smith, H. R. \& Rowe, B. (1996). Verocytotoxin-producing Escherichia coli O157, particularly serogroup O157, associated with human infections in England and Wales: 1992-4. Epidemiol Infect 117, 1-10.

Tsai, C.-M. \& Frasch, C. E. (1982). A sensitive silver stain for detecting lipopolysaccharide in polyacrylamide gels. Anal Biochem 119, 115-119.

Westphal, O. \& Jann, K. (1965). Bacterial lipopolysaccharides. Extraction with phenol-water and further application of the procedure. Methods Carbohydr Chem 5, 83-91.

Willshaw, G. A., Cheasty, T., Smith, H. R., O'Brien, S. J. \& Adak, G. K. (2001). Verocytotoxin-producing Escherichia coli (VTEC) O157 and other VTEC from human infections in England and Wales: 1995-1998. J Med Microbiol 50, 135-142.

Wray, W., Boulikas, T., Wray, V. P. \& Hancock, R. (1981). Silver staining of proteins in polyacrylamide gels. Anal Biochem 118, 197-203. 